\section{Ny kunnskap om antistoff mot blodplater hos gravide}

\author{
Norske forskere har kartlagt deler av den cellulære immunresponsen \\ ved neonatal alloimmun trombocytopeni.
}

Neonatal alloimmun trombocytopeni er en tilstand som rammer fostre og nyfødte. De aller fleste tilfellene forårsakes av en maternell antistoffrespons rettet mot HPA1a på fosterets trombocytter. Mer enn $90 \%$ av kvinner som danner anti-HPA-1a-antistoffer i forbindelse med svangerskapet, har et bestemt MHC-klasse II-allel: HLADRB3*0101. Til sammenlikning finnes dette allelet hos færre enn $30 \%$ i den øvrige befolkningen. Denne sterke assosiasjonen mellom neonatal alloimmun trombocytopeni og et bestemt MHC-molekyl tyder på at HPA-1a-spesifikke antistoffresponser er avhengige av T-lymfocytter. Det er begrenset kunnskap om cellulære immunresponser assosiert med denne tilstanden.

- I en ny studie isolerte vi CD4-positive T-lymfocytter fra kvinner som hadde født barn med neonatal alloimmun trombocytopeni (1). Disse T-lymfocyttene kunne aktiveres med syntetisk HPA-1a-peptid til proliferative responser og utskilling av cytokiner, sier professor Anne Husebekk ved Universitetet i Tromsø.

- Videre eksperimenter viste at de isolerte T-lymfocyttene kunne aktiveres med HPA-1a-peptid kun i kombinasjon med HLA-DRB3*0101. Likeledes fant vi at T-lymfocyttene kunne aktiveres ved stimulering med en kombinasjon av monocytter og trombocytter forutsatt at monocyttene uttrykte HLA-DRB3*0101-molekylet og trombocyttene var fra en HPA-1a-positiv donor - andre kombinasjoner ga ingen aktivering.

Disse funnene viser at HPA-1a-spesifikke, HLA-DRB3*0101-restrikterte T-lymfocytter kan isoleres fra kvinner som føder barn med neonatal alloimmun trom-

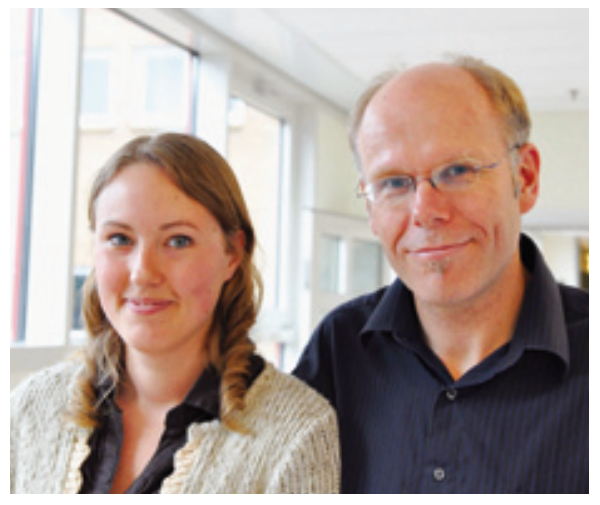

Maria Therese Ahlen og Tor B. Stuge er hhv. første- og sisteforfatter av artikkelen. Foto Informasjonsavdelingen, Universitetssykehuset NordNorge

bocytopeni. Siden disse HPA-1a-spesifikke T-lymfocyttene er avhengig av et bestemt MHC-molekyl som også finnes hos de aller fleste kvinner med anti-HPA-1a-antistoffer, tyder det på at disse T-lymfocyttene er direkte involvert i den cellulære immunresponsen hos kvinner som danner antiHPA-1a-alloantistoff. Studien er derfor et viktig første ledd i å kartlegge den cellulære immunresponsen assosiert med neonatal alloimmun trombocytopeni, sier Husebekk.

\section{Erlend Hem}

erlend.hem@medisin.uio.no

Tidsskriftet

\section{Litteratur}

. Ahlen MT, Husebekk A, Killie MK et al. T-cell responses associated with neonatal alloimmune thrombocytopenia: isolation of HPA-1a-specific HLA-DRB3*0101-restricted CD4+ T cells. Blood 2009: 113: $3838-44$

\section{Ordforklaringer}

Neonatal alloimmun trombocytopeni (NAIT) forekommer i 1:1200 svangerskap og innebærer at den gravide blir immunisert mot et blodplateantigen som fosteret har arvet fra far. Disse antistoffene kan passere placenta, medføre trombocytopeni og blødningstendens og i verste fall intrakranial blødning og død.

Alloantistoff: Antistoff laget av et individ mot antigener $i$ et annet individ innenfor samme art

HPA: Humane blodplateantigener

Er du i ferd med å publisere eller har du nylig publisert i et internasjonalt tidsskrift? Send tips til erlend.hem@medisin.uio.no

www.tidsskriftet.no/norskforskning

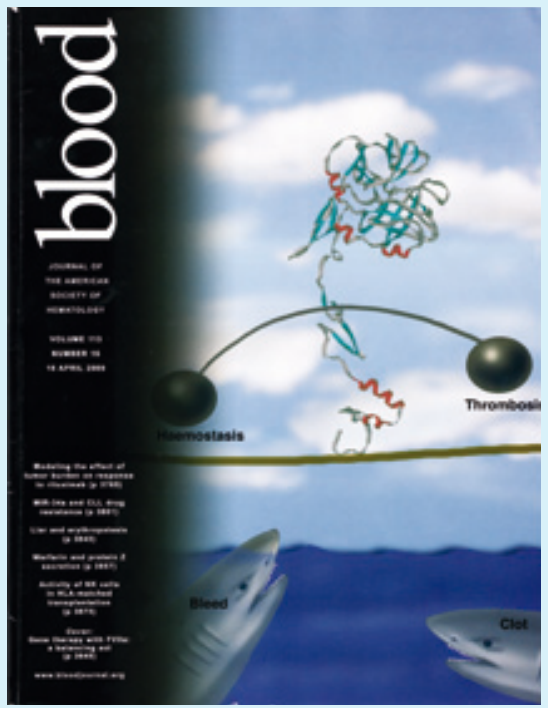

Artikkelen ble publisert på nett 9.1. 2009 og i papirform 16.4. 2009 i det prestisjetunge tidsskriftet Blood (www.bloodjournal.org). (c) American Society of Hematology giske, økonomiske og basale immunologiske aspekter ved neonatal alloimmun trombocytopeni i samarbeid med Oslo universitetssykehus og flere utenlandske forskergrupper. I Tromsø teller gruppen ni medlemmer, derav fire leger, én forskerlinjestudent og fire forskere med biologisk bakgrunn.

\footnotetext{
Litteratur

Hem E. Trombocytopeni før og etter fødselen.

Tidsskr Nor Lægeforen 2007; 127: 2351.
} 